OPEN ACCESS

Edited by:

Xiekang Wang,

Sichuan University, China

Reviewed by:

Qi Yao,

China Earthquake Administration,

China

Joern Lauterjung,

Helmholtz Centre Potsdam, Germany

${ }^{*}$ Correspondence:

Qiming Zhong

qmzhong@nhri.cn

Specialty section:

This article was submitted to

Geohazards and Georisks,

a section of the journal

Frontiers in Earth Science

Received: 26 January 2021

Accepted: 24 March 2021

Published: 14 April 2021

Citation:

Mei S, Chen S, Zhong $Q$ and Shan Y (2021) Effects of Grain Size

Distribution on Landslide Dam Breaching-Insights From Recent

Cases in China.

Front. Earth Sci. 9:658578. doi: 10.3389/feart.2021.658578

\section{Effects of Grain Size Distribution on Landslide Dam Breaching - Insights From Recent Cases in China}

\author{
Shengyao Mei ${ }^{1,2}$, Shengshui Chen ${ }^{1,3}$, Qiming Zhong ${ }^{1,3 *}$ and Yibo Shan ${ }^{1,2}$ \\ ${ }^{1}$ Department of Geotechnical Engineering, Naniing Hydraulic Research Institute, Nanjing, China, ${ }^{2}$ College of Civil and \\ Transportation Engineering, Hohai University, Nanjing, China, ${ }^{3}$ Key Laboratory of Failure Mechanism and Safety Control \\ Techniques of Earth-Rock Dam of the Ministry of Water Resources, Nanjing, China
}

Landslide dams are common geological features in mountainous areas, which may have serious consequences due to sudden breaching of the dam. An effective emergency response requires rapid and accurate forecasts regarding the landslide dam breach process. However, most existing models use physical, mechanical, and erosion properties of the mean or characteristic grain sizes to represent the landslide deposits. The grain size distribution and variations in soil erodibility with the depth in the landslide dam are not considered, resulting in an incorrect estimation of the breach flow hydrograph. In this paper, a simplified landslide dam classification is presented based on the formation mechanism and grain size distribution of landslide dams. Additionally, the influences of grain size distribution on the residual dam height and breach process of landslide dams are analyzed. This paper proposes a numerical method to rapidly obtain the breach hydrographs and breach morphology evolution of landslide dams. The new method can quickly classify landslide dams according to geological survey data and predict the landslide dam breach process. Three types of representative landslide dams in China are simulated to validate the proposed method. The breach flow discharge is significantly affected by spillway excavation. This contribution can provide rapid prediction of the landslide dam breach process and can be used for the emergency response planning before dam breaching.

Keywords: landslide dam, grain size distribution, classification method, breach mechanism, numerical method

\section{INTRODUCTION}

Landslide dams are common geological features in mountainous area around the world that block rivers to form dammed lakes. In recent years, affected by climate change, massive earthquakes, and human activity, the frequency of extreme weather and geological disasters have increased the number of dammed lakes. According to statistics of 1,393 landslide dams (Shen et al., 2020), since the twenty-first century, there have been 362 documented cases of dammed lakes in China. Unlike artificial embankment dams, most landslide dams are formed by rapid accumulation of rock or debris rather than mechanical compaction; hence, the failure risk of landslide dams is much higher than that of embankment dams. $89 \%$ of landslide dam failures are caused by overtopping, and nearly $10 \%$ are caused by piping (Zhong et al., 2018). The longevity of landslide dams is uncertain and can last from a few minutes to many years. Of 73 failed landslide dams 
(Costa and Schuster, 1988), 85\% lasted less than 1 year, and 27\% lasted less than 1 day. Similar conclusions have been drawn after statistical analyses of 204, 276, and 352 landslide dams, respectively (Shi et al., 2011; Peng and Zhang, 2012; Shen et al., 2020). Once an outburst of landslide dams occurs, massive flooding may occur in a short time, posing a catastrophic threat to the lives and properties of downstream residents. For instance, the collapse of the Diexi landslide dam in Sichuan Province due to an earthquake caused nearly 2,500 deaths in 1933 (Liu et al., 2016). The peak breach discharge reached $124,000 \mathrm{~m}^{3} / \mathrm{s}$ during the outburst of the Yigong landslide dam occurred in the Tibetan Plateau in 2000, resulting in the homelessness of millions of people (Wang et al., 2016). Therefore, a rapid and accurate prediction of the overtopping-induced breach process of landslide dams is of great importance to emergency response and disaster mitigation.

Generally, the existing breach models for the dams composed of earth and rockfill materials can be categorized into two types: empirical models and physical models (ASCE/EWRI Task Committee on Dam/Levee Breach, 2011; Zhong et al., 2016). Empirical models commonly use logistic regression to predict the dam breaching parameters based on the dam failures; however, these models are unable to give the breach flood hydrographs and rarely consider the physical and mechanical properties of dam materials. Physical models consider the hydrodynamic and soil erosion conditions during the dam breach process. In this study, a physical model is considered.

Different from embankment dams, landslide dams have a more complex structure and grain size distribution. In addition, the stratification of dam materials varies for landslide dams with different accumulation forms (Fan et al., 2020). Due to the heterogeneity of landslide dam deposits, landslide dams commonly have a residual dam height after breaching (Zhong et al., 2018). However, data on the grain size distribution with depth in the landslide dam are rarely available; therefore, most of the models used the physical, mechanical, and erosional properties of the mean or characteristic grain sizes to represent landslide deposits. In the emergency disposal, the safest prediction may be calculated by assuming a complete breach, so the breach will be assumed to extend to the dam foundation. Although a few models can predefine the residual dam height by limiting the bottom elevation of the breach before simulation (Chen et al., 2015; Zhong et al., 2018), determining the residual dam height is still a difficult problem. For landslide dams with huge upstream storage, the residual dam height has a significant impact on the released storage, especially for the peak breach discharge (Zhong et al., 2018). At the Tangjiashan landslide dam breach in Sichuan Province in China, large number of unjointed rock masses at the lower part resulted in a large residual dam height after breaching (Figure 1). Sensitivity analysis showed that, if the breach developed to the dam foundation, the peak discharge would have been approximately 5 times greater than the measured value (Zhong and $\mathrm{Wu}, 2016$ ). Consequently, due to the wide gradation of landslide dam deposits and variations in soil erodibility with dam depth (Chang and Zhang, 2010; Chang et al., 2011), traditional dam breach models should not be applied any longer (Zhong et al., 2020a).

\section{Structure of This Article}

This article aims to apply stratification characteristic of landslide dam to numerical simulation to analyze the effects of grain size distribution on landslide dam breaching. Section "Formation and Characteristics of Landslide Dams" presents the relationship between the formation mechanisms and grain size distributions of landslide dams. Furthermore, a simplified landslide dam classification system is proposed and three different types of landslide dams in China (see Table 1) are analyzed. Then, the breach mechanisms and processes of landslide dams are summarized in section "Landslide Dam Breach Mechanisms and Processes". Section "Numerical Method" introduces the numerical method that rapidly predicts the dam breach process. According to the grain size distribution of each layer and the breach mechanism, improvements are made based on the numerical model of Zhong et al. (2020a). The breach processes of three representative landslide dams are simulated to verify the proposed method in section "Case Studies". The breach characteristics of landslide dams are investigated using the obtained breach hydrographs and the evolution of breach morphology. The impacts of spillway excavation on the landslide dams breaching are also analyzed.

\section{FORMATION AND CHARACTERISTICS OF LANDSLIDE DAMS}

Many of the landslides cannot form dammed lakes. For convenience, all the landslide dams in this paper refer to natural accumulations that can completely block a river and form a dammed lake. The geometries and material properties depend on the landslide dam formation processes and significantly affect the breach processes (Fan et al., 2020). For this reason, the formation mechanisms and grain size distributions of landslide dams are summarized, and a simplified landslide dam classification is proposed.

\section{Landslide Dam Formation Mechanism}

According to a statistical analysis of 1,393 landslide dams worldwide (Shen et al., 2020), the triggering factors of riverdamming landslides were earthquakes (50.5\%), rainfall (39.3\%), snowmelt (2.4\%), human activities (2.2\%), and volcanic eruptions $(0.9 \%)$. Cases with unknown causes occupied $4.7 \%$. The most prominent forms of landslides leading to the formation of dams are rockslides, rock avalanches, and flows in unconsolidated sediments, which are primarily triggered by earthquakes and rainfall (Cruden and Varnes, 1996; Evans et al., 2011). Here the descriptions show how landslides of three types may evolve.

Natural rockslides often occur high on the valley or mountain flanks, which pose serious threats to large areas along the valley bottom. Due to the progressive failure of the rock mass or an external movement which can induce slope instability, the rockslides can rapidly evolve in a relatively short time. This downslope movement occurs mainly on surfaces of rupture or on weak zones of strong shear strain. Often the initial signs of slide movement are cracks in the original sliding surface along which the main scarp will form. When the shear stress on a potentially weak structural surface exceeds the shear strength, the 


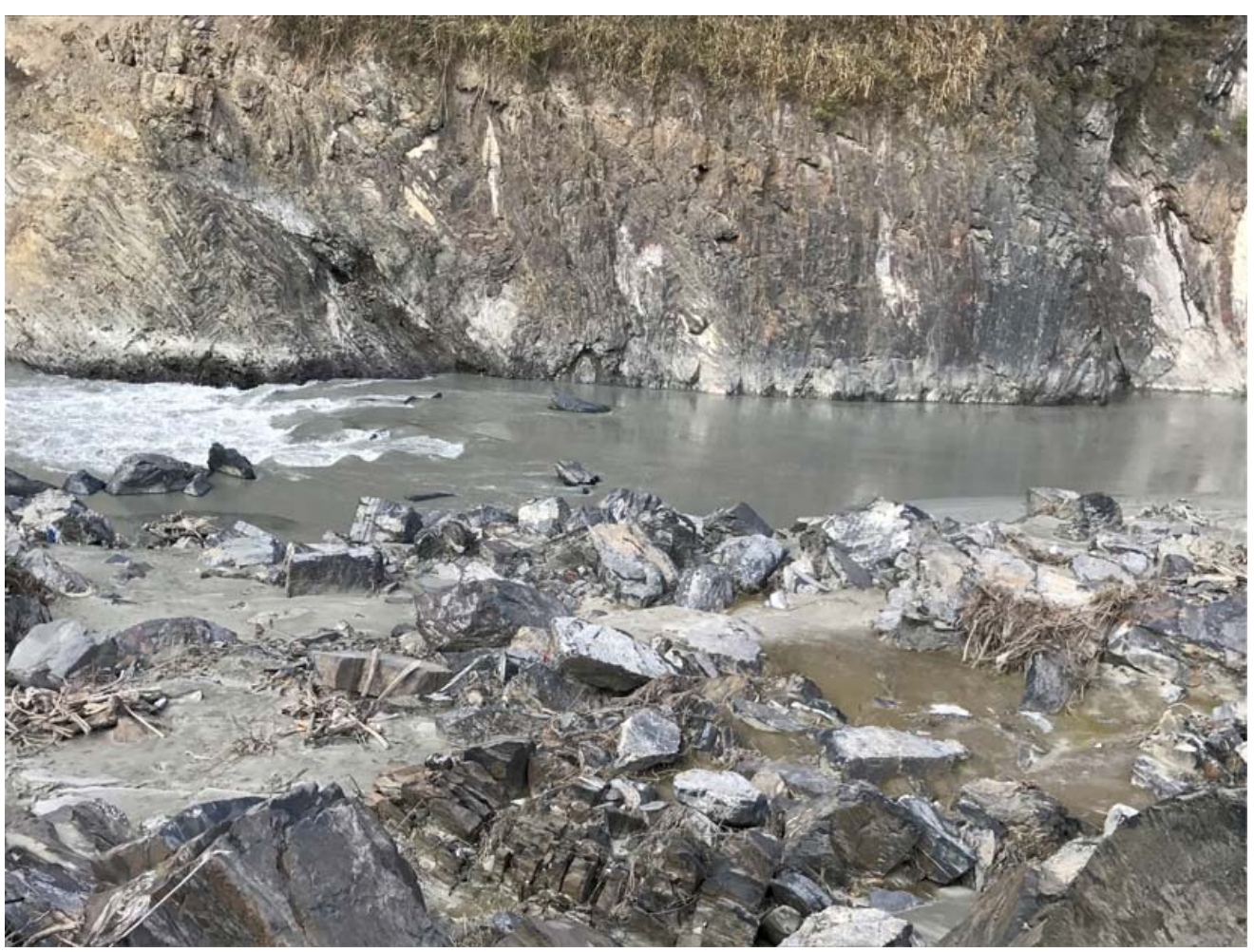

FIGURE 1 | Photograph of Tangjiashan landslide dam at the breach site more than 12 years after the outburst flood (imaged on December 21, 2020).

TABLE 1 | Photos and profiles of three landslide dams, red arrows indicate the position and direction of the longitudinal section
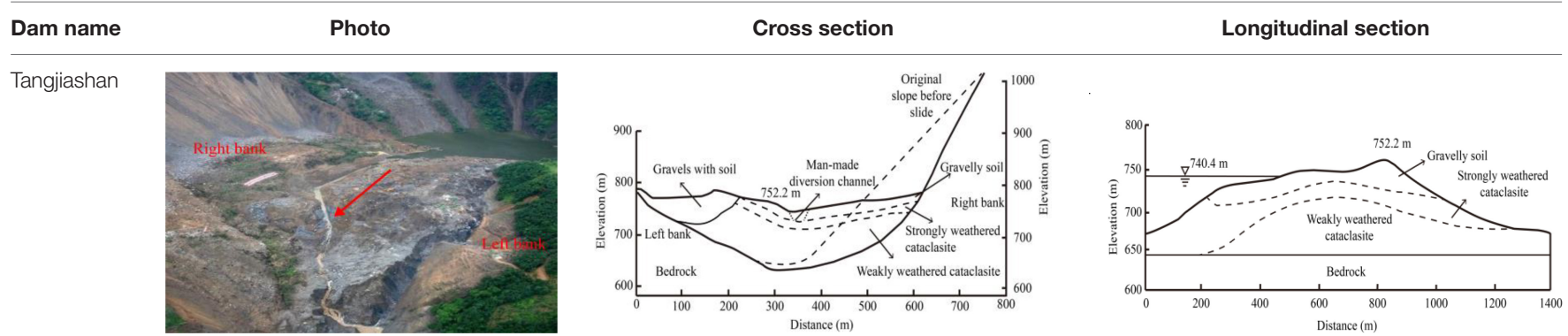

Xiaogangjian
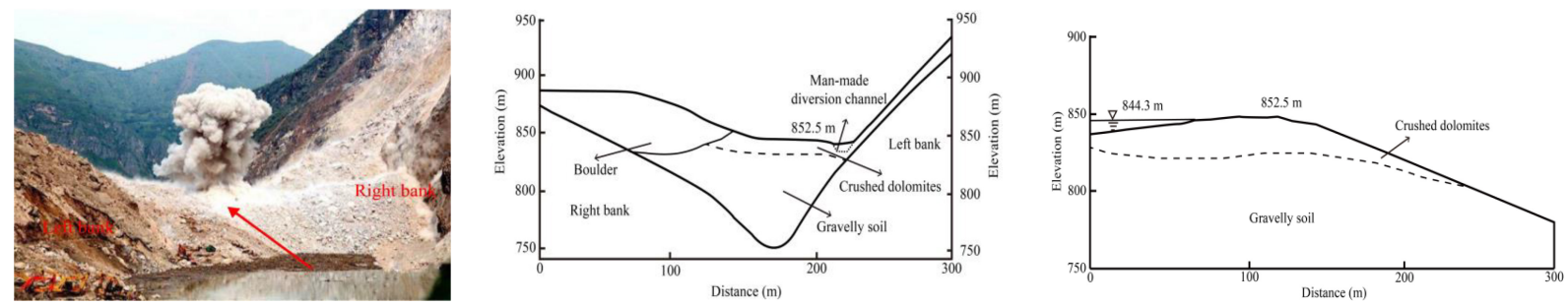

"11.03" Baige
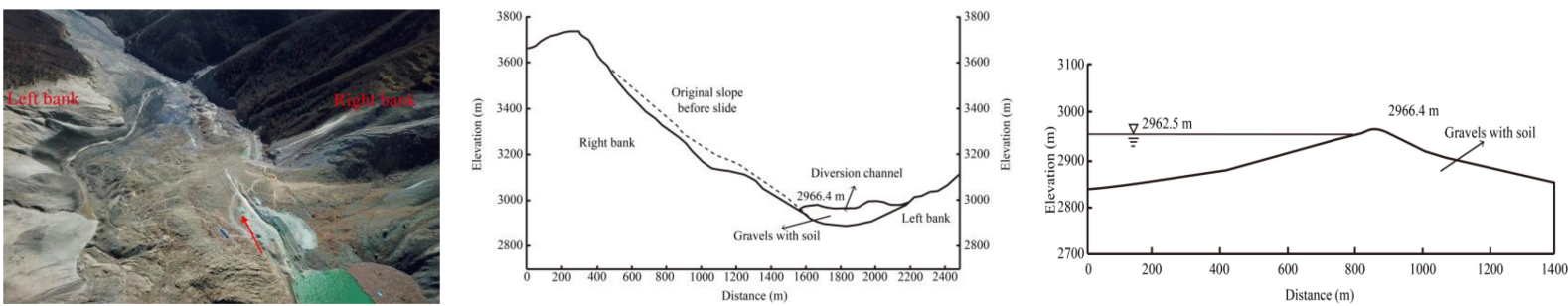
rock slides at high speed along the sliding surface and dams the river (Figure 2A). Due to the short sliding length, the sliding body cannot completely disintegrate, part of which still maintains the original structural features (Fan et al., 2017).

Rock avalanches commonly occur when the upper rock and soil from steep slopes are cut and split by cracks. The material then drops by falling, leaping, or rolling. Large rock masses lose stability under external loads, blocking the river (Figure 2B). Both rockslides and rock avalanches are derived from relatively intact bedrock; however, their movement tracks are different. Rockslides generally slide in an approximately linear trajectory (Gruber et al., 2009; Erismann and Abele, 2013). However, rock avalanches commonly break up suddenly in the direction of the maximum gravity gradient, strike the steep slope, and spread radially.

The flows in unconsolidated sediments may be a spatially continuous movement in which grain contact surfaces are shortlived and usually not retained. Debris may be added to the flows by rainfall erosion or rock collapse, increasing the power of flows. The flows may become extremely rapid debris flows as the mixed material loses cohesion or encounters steeper flanks. Therefore, landslide dams formed by flows in unconsolidated sediments are commonly not dominated by rock structure. Large number of loose materials move in a comprehensive flow form under the action of high-speed sliding and mutual collision, and finally accumulate on the river channel (Figure 2C).

\section{Grain Size Distribution of Landslide Dam}

Landslide dams are formed by natural rock and soil accumulation without manual selection. The grain size distribution of landslide dams varies significantly due to the different landslide dam formation processes (Dunning and Armitage, 2011). Landslide dams formed by flows in unconsolidated sediments are usually composed of fine particles because the high rocks fall and break over long distances into debris. However, dams formed by rockslides and rock avalanches are primarily rock dams with short sliding distances. Broken rock masses form the skeleton of these two dam types. Furthermore, the differences in grain size distribution of the landslide dams lead to differences in dam properties. For example, the erosion resistance of landslide dams with more block stones is stronger than for a dam containing more fine particles (Costa and Schuster, 1988).

Differences in the horizontal and vertical grain size distributions of landslide dams are also obvious. Even within the same landslide dam, the grain size distributions and material properties at different positions are quite different. For example, as shown in Table 1, the left side of Tangjiashan landslide dam has a higher terrain (Liu et al., 2016), which has more rock fragments. However, the upper right side is primarily gravelly soil with a small grain size. The place with the lowest elevation is commonly chosen to excavate the spillway during an emergency response. Therefore, this paper focuses on vertical variations of grain size distribution characteristics, while horizontal variations are not considered. According to the measured data and laboratory test results of the Tangjiashan and Xiaogangjian landslide dams (Chang and Zhang, 2010; Zhang et al., 2019), the critical shear stress values of landslide dams gradually increase with depth,
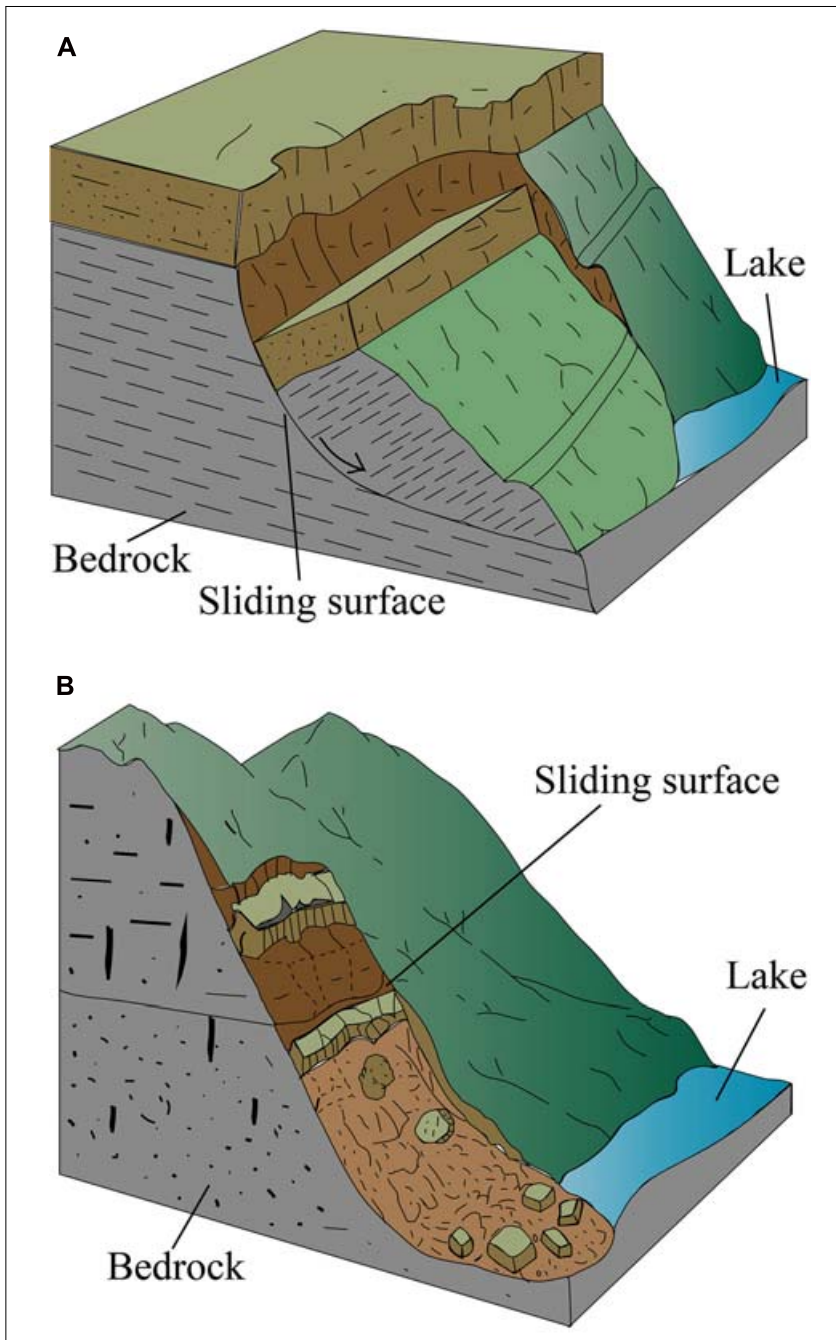

C

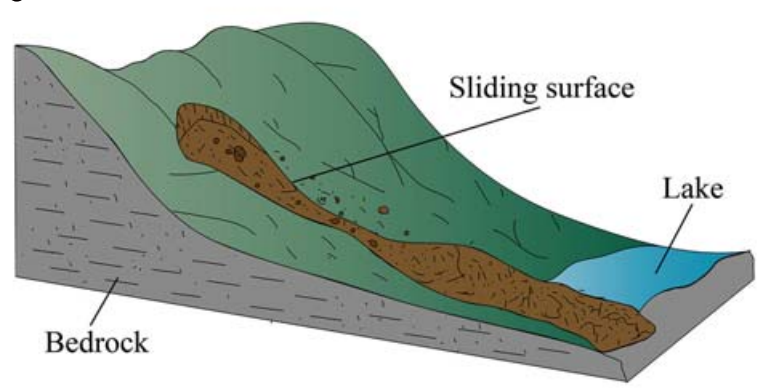

FIGURE 2 | Formation of landslide dams: (A) dam formed by rockslides; (B) dam formed by rock avalanches; (C) dam formed by flow in unconsolidated sediments.

while porosity and erosion rate decrease. Therefore, a landslide dam can be stratified according to erodibility and grain size distribution (Fan et al., 2020). 
For that reason, a simplified landslide dam classification system is proposed (see Table 2), which accounts for the internal geological structure and can be used to quickly identify the landslide dam during an emergency response. Here three corresponding representative landslide dams in China are proposed (see Figure 3) and their grain size distribution characteristics are introduced, respectively, as follow.

The Tangjiashan landslide dam formed by an earthquaketriggered rockslide, $4 \mathrm{~km}$ upstream of Beichuan county town on the Tongkou River, Sichuan Province, is a good example of type I. It was formed by a rockslide in fragmented bedrock composed of siltstone, siliceous rock blocks and mudstone of the Qingping Group, from the lower Cambrian. Gravelly soil from the residual slope of the original mountain accounts for about $14 \%$, and cataclasite accounts for $86 \%$ of the landslide (Liu et al., 2016; Figures 4a,b). Based on the cross and longitudinal section of the dam profile, the dam foundation is the bedrock of the original slope (Figure 4c), the lower part consists of weathered cataclasite, and the surface layer contains mostly gravelly soil (see Table 1). Therefore, the Tangjiashan landslide dam can be divided into three layers according to the grain size distribution characteristics.

The Xiaogangjian landslide dam located in the upper reach of the Mianyuan River, Sichuan Province, is an example of a type II dam. The dam body is primarily composed of boulders and crushed dolomites with fine-grained soil fill (see Table 1). The large boulders and blocks with grain sizes of 0.5-3 $\mathrm{m}$ account for $75 \%$ (Figure 4d), and soil and rock fragments with grain sizes of

TABLE 2 | Simplified landslide dam classification system.

\begin{tabular}{|c|c|c|c|}
\hline Type & Description & Dam material & Stratification \\
\hline I & $\begin{array}{l}\text { This type of landslide dam is primarily } \\
\text { formed by rockslides that are one } \\
\text { solid mass. Part of the rock mass at } \\
\text { the bottom of the sliding body still } \\
\text { maintain the original structural } \\
\text { features. The internal structure of the } \\
\text { rock mass can be divided into various } \\
\text { layers with different grain size and } \\
\text { properties for each layer }\end{array}$ & $\begin{array}{l}\text { The bottom layer is } \\
\text { relatively intact } \\
\text { strata, and the } \\
\text { middle layer is } \\
\text { largely composed } \\
\text { of fragmented } \\
\text { rocks topped by } \\
\text { debris }\end{array}$ & $3-4$ \\
\hline$\|$ & $\begin{array}{l}\text { Dams of this type are commonly } \\
\text { formed by rock avalanches from } \\
\text { steep slopes. During the landslide } \\
\text { process, the original rock is basically } \\
\text { disintegrated with boulders } \\
\text { distributed along the front edge of the } \\
\text { deposits. In many cases, dams of this } \\
\text { type could have a dual structure with } \\
\text { crushed debris inside covered by } \\
\text { blocky carapace (Davies and } \\
\text { McSaveney, 2002) }\end{array}$ & $\begin{array}{l}\text { The dam body } \\
\text { primarily consists of } \\
\text { large boulders and } \\
\text { fine-grained } \\
\text { materials, such as } \\
\text { debris, fill the } \\
\text { framework between } \\
\text { the boulders and } \\
\text { blocks }\end{array}$ & 2 \\
\hline III & $\begin{array}{l}\text { Such landslide dams commonly have } \\
\text { huge terrain elevation differences, so } \\
\text { the potential energy is huge. Since } \\
\text { the landslide body has a long } \\
\text { movement along the travelling path, } \\
\text { the dam materials are relatively loose, } \\
\text { unstable, and easily erodible }\end{array}$ & $\begin{array}{l}\text { This dam body } \\
\text { primarily consisted } \\
\text { of unconsolidated } \\
\text { fine debris } \\
\text { consisting of gravel } \\
\text { size particles as } \\
\text { well as finer } \\
\text { material }\end{array}$ & $1-2$ \\
\hline
\end{tabular}

5-30 $\mathrm{cm}$ account for $25 \%$ of the landslide dam (Figure 4e). The height of one of the large boulders found in the field is about $10 \mathrm{~m}$ (Chen et al., 2018). Large rocks were concentrated on the top of the dam, so the dam body can be roughly divided into two layers.

The "11.03" Baige landslide dam occurred in the provincial border between Sichuan and Tibet, is a good case of a type III dam. The dam primarily consists of sand and gravel mixed with gravelly soil (see Table 1). Highly fractured but relatively undisaggregated clasts are common, and the grain size distribution is uniform (Figure 4f). For simplicity, the dam structure can be treated as one layer from top to bottom.

\section{LANDSLIDE DAM BREACH MECHANISMS AND PROCESSES}

Breach mechanism in this paper simply refers to overtoppinginduced dam breach, regardless of piping. Most landslide dams have large length-width aspect ratios, so the analysis should focus on the change in dam geometry along the river during dam breaching as well as breach development at the dam crest and downstream slope. Many studies have examined the breach mechanism and process of overtopping-induced landslide dams (Zhong et al., 2020a). Through small-scale physical model tests (Zhang et al., 2010; Niu et al., 2012; Zhou et al., 2019), it was determined that landslide dam erosion primarily manifests as surface erosion during dam collapse. The morphological evolution of the dam longitudinal slope (Zhang et al., 2010) indicates that the top of the breach begins to erode first, and the downstream slope erodes backward, further reducing the downstream slope angle. Consequently, these mechanisms should be fully considered in order to reasonably predict the breach processes of landslide dams.

The breach process of landslide dams can be divided into three stages (Zhang et al., 2019; Cai et al., 2020; Zhong et al., 2020b). The first stage is uniform bed erosion. In the initial stage of erosion, only the fine particles in the surface layer are eroded due to the low water level and slow flow velocity at the breach. In this stage, the inflow exceeds outflow, so the lake level continues to increase. Breaching is initiated when significant erosion of the spillway begins. The second stage is backward erosion. As the upstream water level continues to rise, the flow velocity increases. Overtopping may be initiated by static overflow, resulting in erosion of the downstream dam toe first. The depth and width of the spillway undergo significant enlargement. The third and final stage is erosion along the flow channel. When the backward erosion reaches the top of the breach, the water head increases suddenly because of the decrease in the elevation of the breach bottom. The collapse of the breach slope causes a swift increase in breach width and flow discharge. This stage is the fastest growing stage for the breach, and the peak flow discharge occurred during this period. The increase in flow discharge causes the reservoir water level to decrease. The dam breach ends when the inflow cannot longer erode the dam material.

Unlike the failure mechanisms of homogeneous earthen dams, the downstream landslide dam slope gradually decreases during the breach process, and the final depth of the breach is affected by 


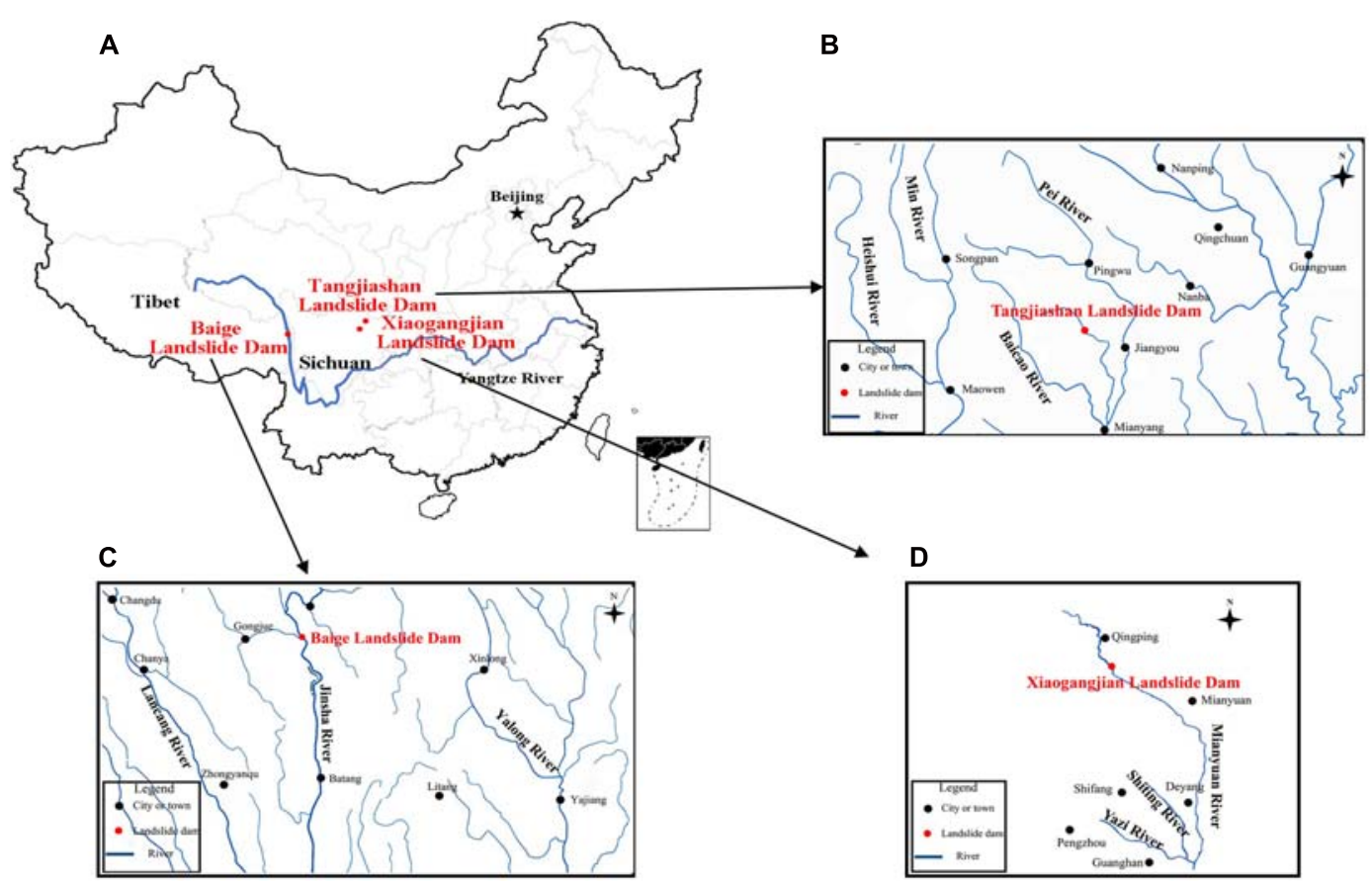

FIGURE 3 | The location of three representative landslide dams.

the grain size distribution of the landslide dam. Centrifugal model tests conducted by Zhao et al. (2019) for overtopping-induced landslide dam breach suggest that breach growth in the depth direction stopped early due to the accumulation of large particles in the downstream slope. For landslide dams with more large blocks, such as the Tangjiashan landslide dam, residual dams after dam breaching are common.

\section{NUMERICAL METHOD}

Once the landslide dam forms, emergency response normally requires rapid prediction of the breach flow discharge and breach size evolution (Chen et al., 2020). A numerical method that rapidly predicts the dam breach process is proposed based on the model of Zhong et al. (2020a).

First, according to the landslide dam formation mechanism and geological survey data, the grain distribution characteristics are used to classify the dam type. The dam body can be divided into several layers, and each layer is assumed to be horizontally distributed. The depth of each layer and the corresponding soil erodibility coefficients are determined from geological surveys or empirical formulas and have significant influence on the subsequent numerical analysis.

Second, numerical simulation of a landslide dam is conducted based on the properties of structures and materials. A calculation method based on time step iteration is utilized to simulate the water and soil coupling during the dam breach process. The mechanical and physical properties as well as the hydrodynamic conditions of the dammed lake are considered. For simplicity, the dam body is treated as a trapezoid in the horizontal and vertical directions. Three-dimension expansion of the breach in longitudinal and cross section directions can be simulated using shear stress analysis; additionally, the limit equilibrium method is adopted to determine the slope mass failure during the dam breach. For incomplete dam breaches, the model determines the final residual dam height according to the erosion properties and distribution of each layer material. The numerical model primarily includes three parts: a hydrodynamic module, a soil erosion module, and a breach evolution module.

\section{(1) Hydrodynamic module}

Overtopping may be initiated by dynamic overflow within the impounded lake. When calculating the breach flow discharge, the lake area, inflow and breach flow under different time and reservoir water levels should be considered, so that the whole process follows the water balance relationship (see Figure 5).

$$
\frac{d z_{s}}{d t}=\frac{Q_{i n}-Q_{b}}{A_{s}}
$$

Where $z_{s}$ is the water level of dammed lake, $t$ is the elapse time, $Q_{i n}$ and $Q_{b}$ are the inflow and breach flow discharge, $A_{s}$ is the surface area of the dammed lake.

The breach flow discharge is calculated by the broad crested weir equation $(\mathrm{Wu}, 2013)$.

$$
Q_{b}=k_{s m}\left(c_{1} b H^{1.5}+c_{2} m H^{2.5}\right)
$$

Where $k_{s m}$ is the correction coefficient of tail water (Fread, 1984), $m$ is the ratio of breach slope (horizontal/vertical); $c_{1}$ and $c_{2}$ are the correction coefficients. Here, $c_{1}=1.7 \mathrm{~m}^{0.5} / \mathrm{s}, c_{2}=1.1 \mathrm{~m}^{0.5} / \mathrm{s}$ 

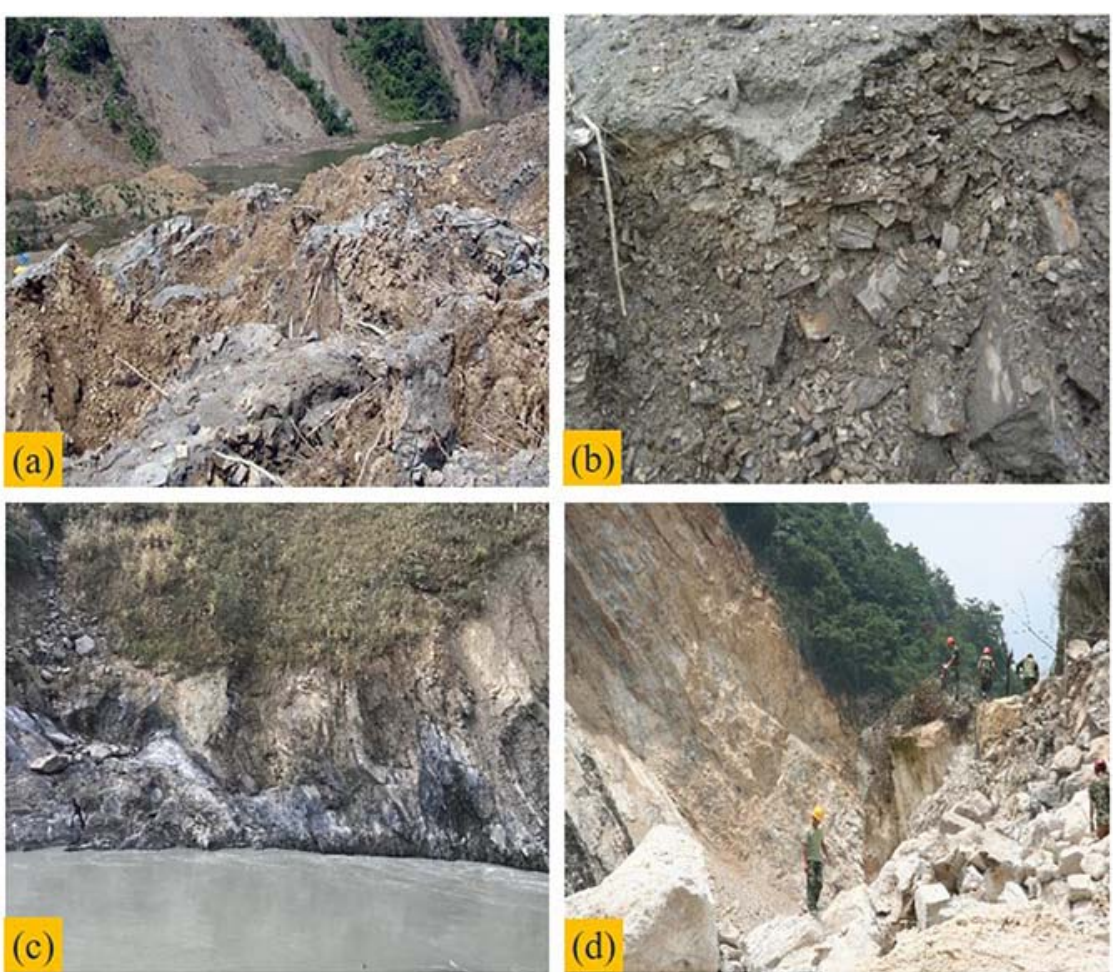

(c)

(d)
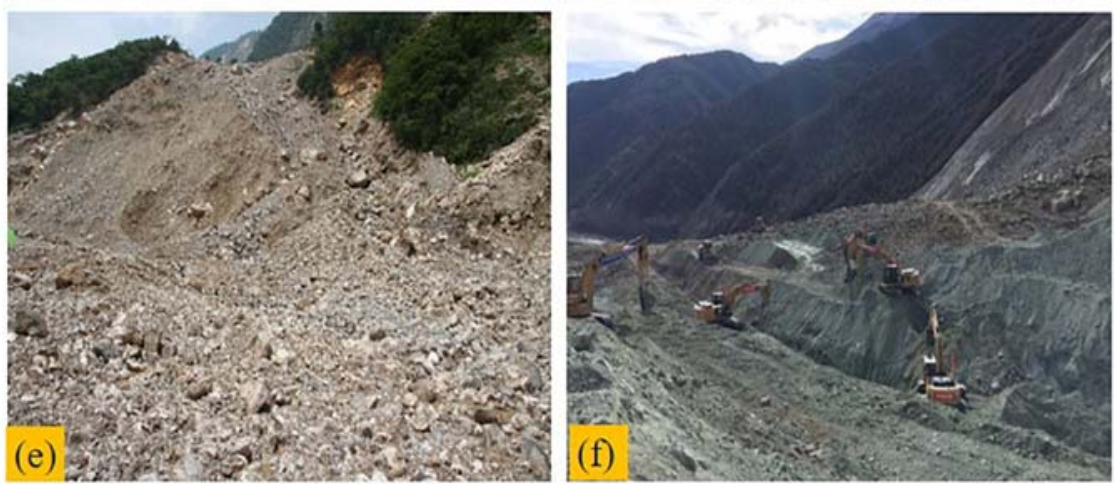

FIGURE 4 | Grain size distribution of landslide dams: (a) gravelly soil; (b) cataclasite; (c) bedrock; (d) boulder; (e) soil and rock fragment; (f) sand and gravel.

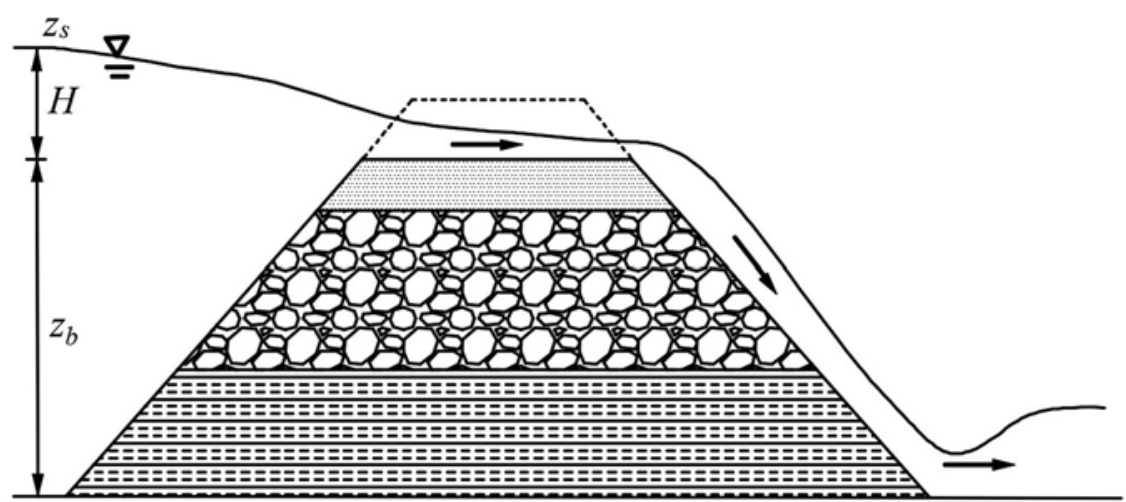

FIGURE 5 | Hydrodynamic condition of the model. 
(Zhong et al., 2020a). $b$ is the breach bottom width, $z_{b}$ is the breach bottom elevation and $H=z_{s}-z_{b}$ is the breach water depth.

(2) Soil erosion module

The erosion rate formula based on the shear stress principle is selected to simulate the erosion rate of each layer of dam material (see Figure 6; Zhang et al., 2019):

$$
\frac{d z_{b}}{d t}=k_{d}\left(\tau_{b}-\tau_{c}\right)
$$

Where $k_{d}=20075 e^{4.77} C_{u}-0.76$ is the erodibility coefficient of soil, $\tau_{b}=\rho_{w} g n^{2} Q_{b}{ }^{2} /\left(A_{s}{ }^{2} R^{1 / 3}\right)$ is the bed shear stress of water, and $\tau_{c}=2 / 3 \cdot \operatorname{gd}_{50}\left(\rho_{s}-\rho_{w}\right) \tan \varphi$ is the soil critical shear stress. Here, $e$ is the void ratio of the soil, $C_{\mathfrak{u}}$ is the uniformity coefficient, $\rho_{w}$ and $\rho_{s}$ is the density of water and soil, $g$ is the gravitational acceleration, $n$ is the Manning's roughness coefficient given by $n=d_{50}^{1 / 6} / 12, R$ is the hydraulic radius, $\mathrm{d}_{50}$ is the median soil size, and $\varphi$ is the soil internal friction angle.

(3) Breach evolution module

According to the above assumptions, the longitudinal shear of each layer is consistent with the transverse expansion velocity, so the expansion rate of breach top width can be expressed as:

$$
\frac{d B}{d t}=\frac{n_{l o c} \cdot\left(d z_{b} / d t\right)}{\sin \beta}
$$

Where $B$ is the breach top width, $n_{l o c}$ is the indicator of breach location $\left(n_{l o c}=1\right.$ and 2 represents one- and two-sided breaches, respectively), and $\beta$ is the breach side slope angle.

The expansion rate of breach bottom width can be expressed as:

$$
\frac{\mathrm{d} b}{\mathrm{~d} t}=n_{l o c} \frac{\mathrm{d} z_{b}}{\mathrm{~d} t}\left(\frac{1}{\sin \beta}-\frac{1}{\tan \beta}\right)
$$

The continuous downcutting and lateral expansion of the breach will lead to the slope instability. In this model, the sliding surface is assumed to be plane (Figure 7). The instability condition of breach slope is:

$$
F_{d}>F_{r}
$$

Where $F_{d}=W \sin \alpha=0.5 \gamma_{s} H_{s}^{2}(1 / \tan \alpha-1 / \tan \beta) \sin \alpha$ is the driving force, and $F_{r}=W \cos \alpha \tan \varphi+C H_{s} / \sin \alpha=0.5 \gamma_{s} H_{s}{ }^{2}(1 / \tan \alpha-$ $1 / \tan \beta) \cos \alpha \tan \varphi+\mathrm{CH}_{s} / \sin \alpha$ is the resistant force. Herein, $W$ is the failure block weight, $\alpha$ is the breach side slope angle after

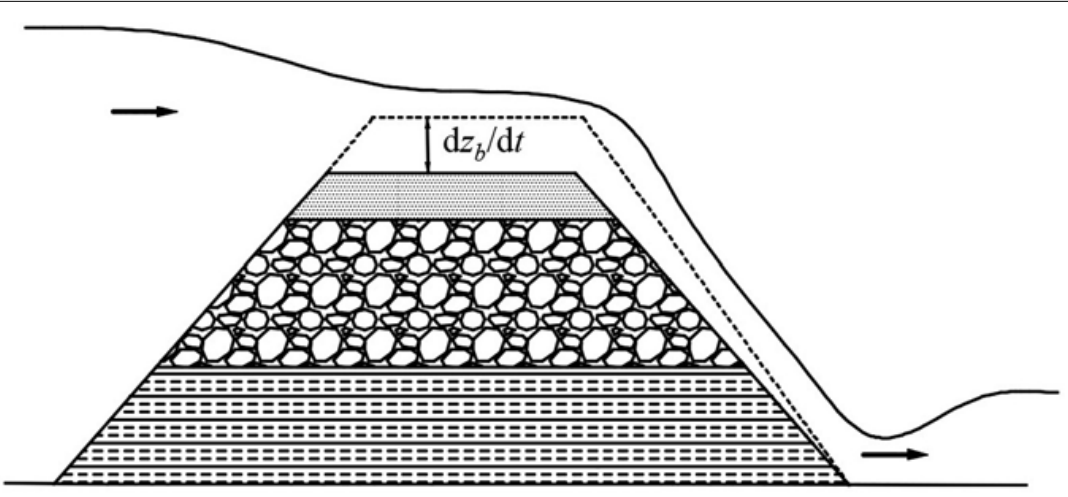

FIGURE 6 | Soil erosion module of the model.

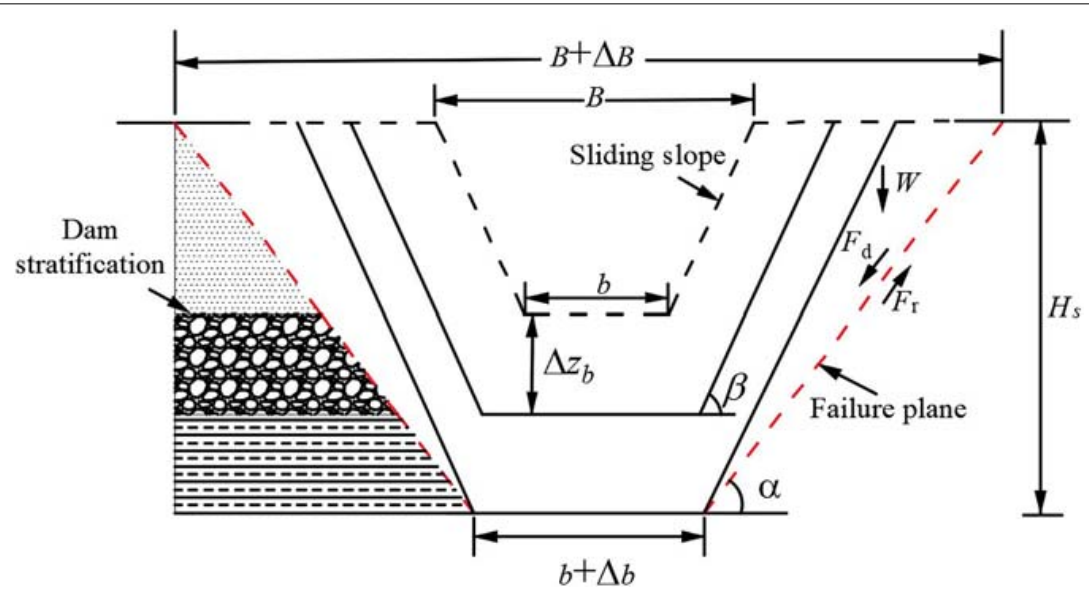

FIGURE 7 | Breach evolution module of the model. 
instability, $\gamma_{s}$ is the soil bulk specific weight, $H_{s}$ is the breach slope height, and $C$ is the soil cohesion.

The flow chart for the numerical method is shown in Figure 8. The calculation time $t_{c}$ and time step can be adjusted by the actual landslide dam failure cases and model tests.
Third, the dam breach process is studied under different engineering conditions. In general, human intervention measures are commonly undertaken to mitigate damage (Peng et al., 2014; Cai et al., 2020). Spillway excavation effectively reduce the maximum possible water volume in the dammed lake and initiate

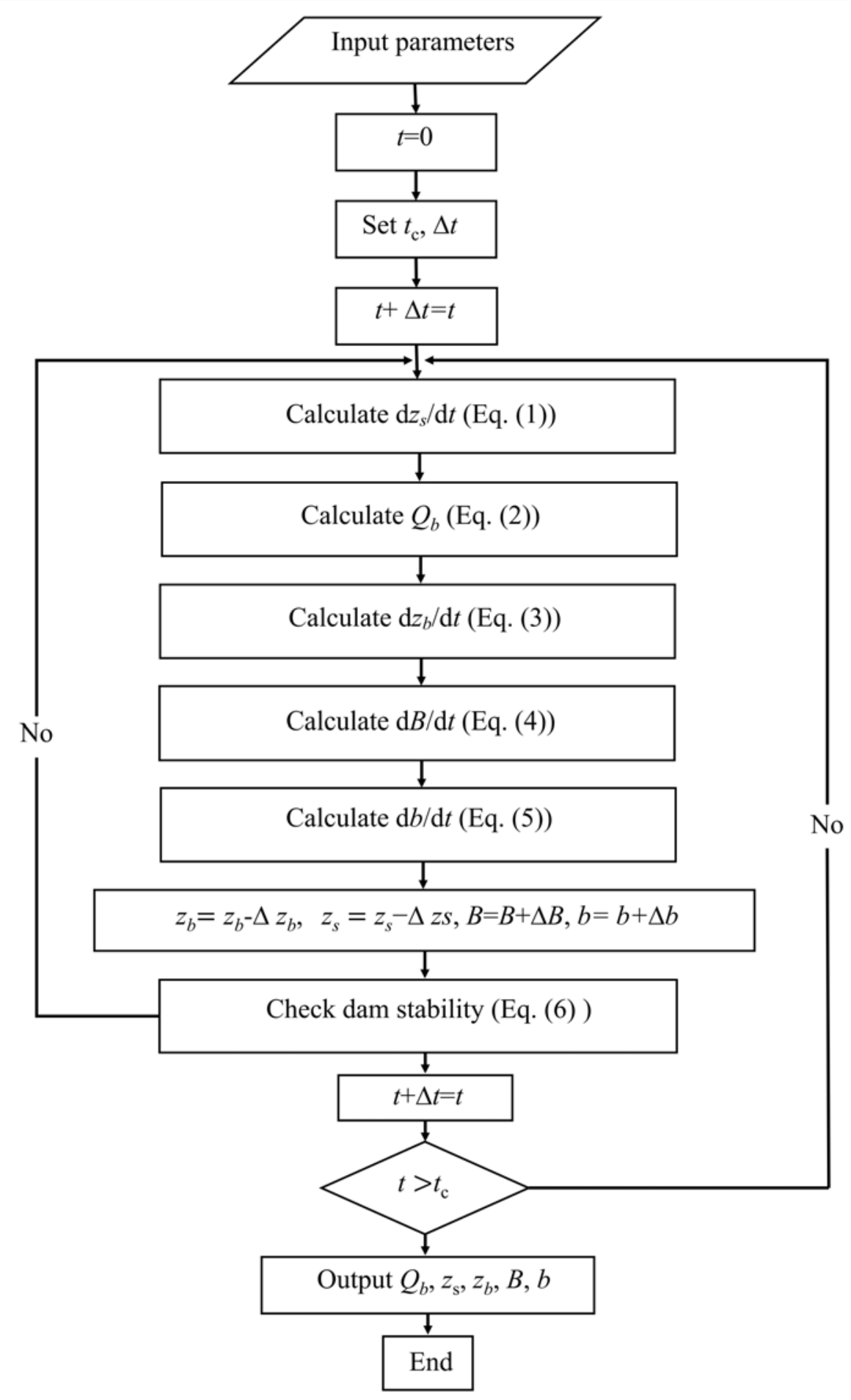

FIGURE 8 | Flow chart of the numerical method. 
TABLE 3 | Primary features of dammed lakes.

\begin{tabular}{|c|c|c|c|c|c|}
\hline Name & Occurrence time & Breach time & Volume $\left(\mathrm{m}^{3}\right)$ & Water storage $\left(\mathrm{m}^{3}\right)$ & Peak breach flow $\left(\mathrm{m}^{3} / \mathrm{s}\right)$ \\
\hline Tangjiashan & May 12, 2008 & June 10, 2008 & $2.4 \times 10^{8}$ & $2.3 \times 10^{8}$ & 6,500 \\
\hline Xiaogangjian & May 12, 2008 & June 12, 2008 & $2.0 \times 10^{6}$ & $1.03 \times 10^{7}$ & 3,950 \\
\hline "11.03" Baige & Nov. 3, 2018 & Nov. 12, 2018 & $2.4 \times 10^{6}$ & $5.78 \times 10^{8}$ & 31,000 \\
\hline
\end{tabular}

a controlled drainage (Zhong et al., 2020a). In order to assess the impact of engineering mitigation measures, a landslide dam with different spillway shapes or without a spillway can be simulated to provide technical support for emergency response measures.

\section{CASE STUDIES}

According to the simplified classification method, the Tangjiashan landslide dam belongs to type I, the Xiaogangjian landslide dam belongs to type II, and the "11.03" Baige landslide dam belongs to type III. Numerous field investigations have been conducted to obtain relatively complete monitoring data for the three landslide dams. Such studies can provide effective input for the numerical analysis of the breach process. The breaching characteristics of landslide dams and the application of the proposed numerical method are demonstrated using case studies of the three representative landslide dams.

\section{Input Parameters}

The specific formation processes of the three landslide dams have been described in detail (Chang and Zhang, 2010; Chen et al., 2015; Cai et al., 2020). The occurrence time and breach time as well as primary features of the dammed lakes are listed in Table 3. The profiles in Table 1 can reasonably reflect the grain size distribution and stratification of each dam. The physical and mechanical parameters of the dam body and each layer were obtained from the pre-event digital elevation information and geological surveys (Tables 4, 5).

\section{Analysis of Calculated Results}

In this subsection, the breach flow discharge, water level variation in the dammed lake, and breach size evolution are considered.

TABLE 4 | Parameters to be entered into the model.

\begin{tabular}{lccc}
\hline Name & Tangjiashan & Xiaogangjian & “11.03" Baige \\
Parameter & & & \\
\hline Dam height $(\mathrm{m})$ & 103 & 72 & 96 \\
Crest width $(\mathrm{m})$ & 300 & 80 & 270 \\
Dam length $(\mathrm{m})$ & 612 & 300 & 600 \\
Upstream slope ratio $(\mathrm{V} / \mathrm{H})$ & $1: 2.8$ & $1: 2.8$ & $1: 2.7$ \\
Downstream slope ratio $(\mathrm{V} / \mathrm{H})$ & $1: 4.2$ & $1: 1.7$ & $1: 5.5$ \\
Initial breach bottom width $(\mathrm{m})$ & 8 & 30 & 3 \\
Initial breach depth $(\mathrm{m})$ & 13 & 8 & 13.48 \\
Initial breach slope ratio & $1: 1.5$ & $1: 2$ & $1: 1.3$ \\
Initial water level $(\mathrm{m})$ & 92.5 & 64.7 & 92.52 \\
$Q_{\text {in }}\left(\mathrm{m}^{3} / \mathrm{s}\right)$ & 80 & 15 & 700 \\
$C(\mathrm{kPa})$ & 25 & 42 & 3 \\
$\varphi($ degree $)$ & 22 & 19 & 35 \\
\hline Note: $\mathrm{V} / \mathrm{H}$ vertical/horizontal. & & & \\
\hline
\end{tabular}

Note: $V / H$ vertical/horizontal.
The calculated and measured breach processes of the three landslide dams were compared in Table 6. Real-time breach evolution data cannot be obtained in emergency situations. Only the final breach morphology was measured. Therefore, in the fourth column of Table 7, the calculated breach evolution curves were compared with the final breach sizes. Furthermore, Table 7 presents the comparison of calculated and measured output parameters for the three landslide dams, including peak breach flow charge $\left(Q_{p}\right)$, final breach top width $\left(B_{f}\right)$, final breach bottom width $\left(b_{f}\right)$, final breach depth $\left(D_{f}\right)$, and time from the first overtopping to peak flow discharge $\left(T_{p}\right)$. The relative errors for all parameters of Tangjiashan landslide dam and " 11.03 " Baige landslide dam remain within $\pm 25 \%$; however, the relative error for breach geometry of Xiaogangjian landslide dam exceeds $\pm 50 \%$. The proposed numerical method can generally estimate the breach hydrograph as well as the evolution of breach morphology.

During an emergency response for landslide dams, it is expected to achieve a rapid initial outflow, relatively low flood speed, small peak breach flow, and large discharge capacity during breaching of the dammed lake. Spillway excavation is currently the preferred manual intervention measure. In order to further verify the influence of spillway excavation on the landslide dam breach process for several dam types, the breach hydrographs are recalculated (Figure 9). It is worth mentioning that the elapsed time here mainly considers the full longevity of landslide dams, which refers to the whole process, from the first overtopping to the end of dam failure. The peak flow discharge, final breach depth, and time from the first overtopping to peak discharge are listed in Table 8.

In the breach flow discharge analysis, the curve showed an extended initial overflow for the Tangjiashan landslide dam. Combined with the grain size distribution of the Tangjiashan landslide dam and the location of the spillway, the spillway depth $(13.48 \mathrm{~m})$ is closed to the depth of the first layer of gravelly soil $(15 \mathrm{~m})$. It is not difficult to infer that the actual erosion surface is cataclasite with a large grain size; therefore, the velocity of erosion was significantly reduced, resulting in extension of initial overflowing time. If the spillway is not excavated, the gravelly soil covered on the top layer will erode first to form the initial breach (Figure 9A). As breach time increases, the final breach depth increase, resulting in an increasing peak breach flow, which poses a great downstream threat.

The discharge process curve of the Xiaogangjian landslide dam has a shape that can be described as "sharp and thin." The curve reaches peak breach flow charge in a short time, resulting in the reservoir water level decreasing quickly. Furthermore, the calculation error for breach geometry of the Xiaogangjian landslide dam is larger than the other two landslide dams 
TABLE 5 | Input parameters for each layer of three landslide dams.

\begin{tabular}{|c|c|c|c|c|c|c|c|}
\hline Name & Layer & Thickness (m) & $e$ & $d_{50}(\mathrm{~mm})$ & $\rho_{s}\left(\mathrm{~kg} / \mathrm{m}^{3}\right)$ & $k_{d}\left[\mathrm{~mm}^{3} /(\mathrm{N} \cdot \mathrm{s})\right]$ & $\tau_{c}(\mathrm{~Pa})$ \\
\hline \multirow[t]{3}{*}{ Tangjiashan } & 1 & 15 & 0.87 & 10 & 1,825 & $1,061.1$ & 4.7 \\
\hline & 2 & 25 & 0.75 & 26 & 2,216 & 249.0 & 17.7 \\
\hline & 3 & 63 & 0.59 & 710 & 2,408 & 36.9 & 330.4 \\
\hline \multirow[t]{2}{*}{ Xiaogangjian } & 1 & 32 & 0.94 & 30 & 2,045 & $1,126.8$ & 31.7 \\
\hline & 2 & 40 & 0.7 & 18 & 1,813 & 276.2 & 14.6 \\
\hline "11.03" Baige & 1 & 96 & 0.6 & 5 & 1,854 & 180.2 & 13.2 \\
\hline
\end{tabular}

TABLE 6 | Comparison of calculated and measured breach processes.

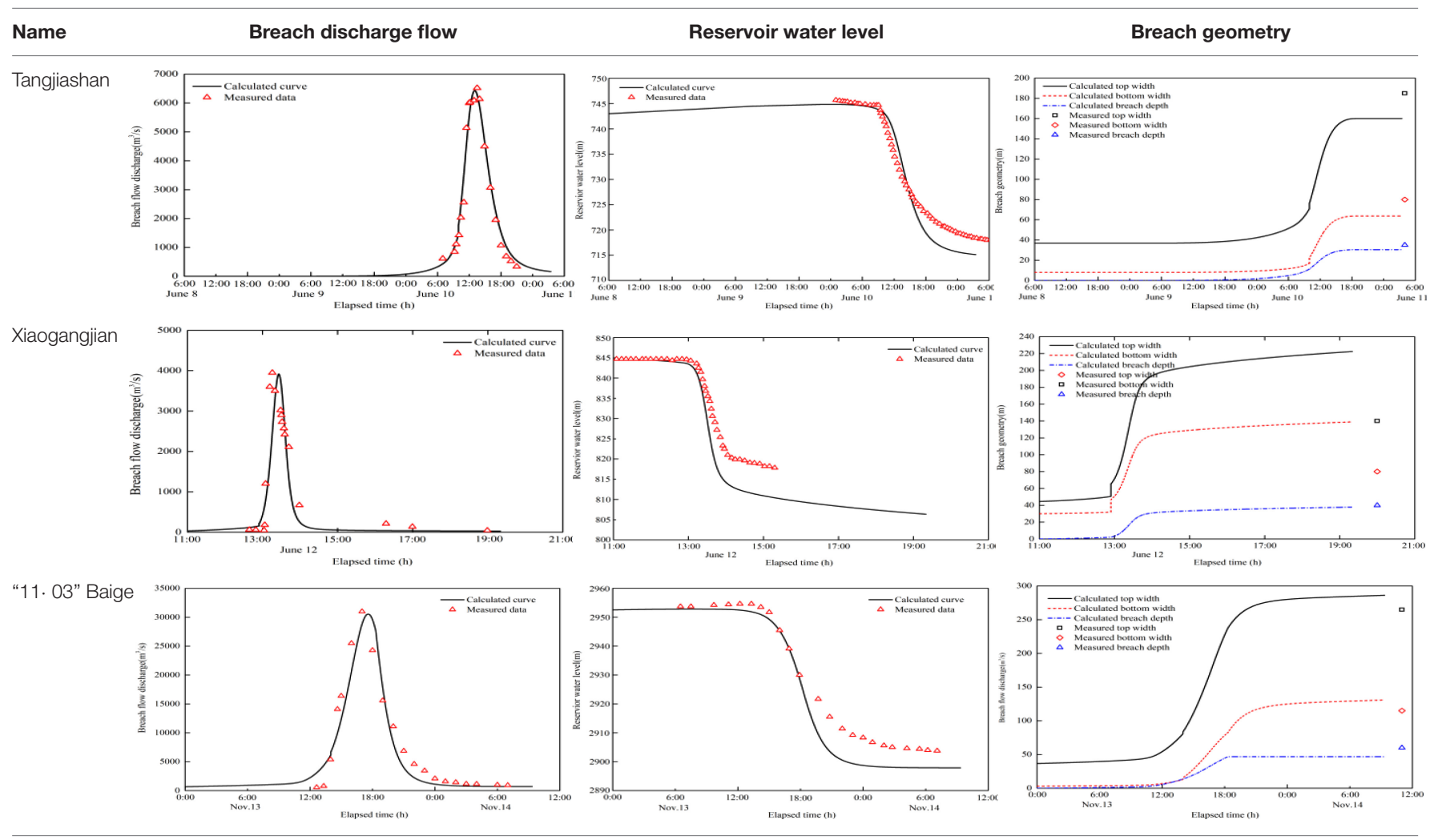

TABLE 7 | Comparison of calculated and measured output parameters for the three landslide dams.

\begin{tabular}{|c|c|c|c|c|c|c|}
\hline Name & Parameter & $Q_{p}\left(m^{3} / s\right)$ & $B_{f}(\mathrm{~m})$ & $b_{f}(\mathrm{~m})$ & $D_{f}(\mathrm{~m})$ & $T_{p}(\mathrm{~h})$ \\
\hline \multirow[t]{3}{*}{ Tangjiashan } & Measured & 6,500 & 186.2 & 83.8 & 35 & 49.92 \\
\hline & Calculated & $6,358.6$ & 165.3 & 64.9 & 31.9 & 47.5 \\
\hline & Relative error & $-2.18 \%$ & $-11.22 \%$ & $-22.55 \%$ & $-8.85 \%$ & $-4.85 \%$ \\
\hline \multirow[t]{3}{*}{ Xiaogangjian } & Measured & 3,950 & 142 & 80 & 40 & 3.0 \\
\hline & Calculated & $3,799.3$ & 217.5 & 126.8 & 36.2 & 3.23 \\
\hline & Relative error & $-3.81 \%$ & $+53.16 \%$ & $+58.83 \%$ & $-9.50 \%$ & $+7.7 \%$ \\
\hline \multirow[t]{3}{*}{ "11.03" Baige } & Measured & 31,000 & 264.1 & 107.8 & 57.1 & 37.25 \\
\hline & Calculated & 30,320 & 288.5 & 121.2 & 45.6 & 38.26 \\
\hline & Relative error & $-2.18 \%$ & $+9.24 \%$ & $+12.43 \%$ & $-20.07 \%$ & $+2.64 \%$ \\
\hline
\end{tabular}

because the Xiaogangjian landslide dam was treated by block blasting, which leads to breaking of the dam surface. The material composition of the dam body is the primary controlling factor for the cohesion $(C)$ and friction angle $(\varphi)$ (Fan et al., 2020).
A decrease in grain size results in a weaker erosion resistance and shorter breach process. In the absence of spillway excavation, due to obstruction of the blocky carapace, the breach time is significantly prolonged (Figure 9B). Once the blocks and 

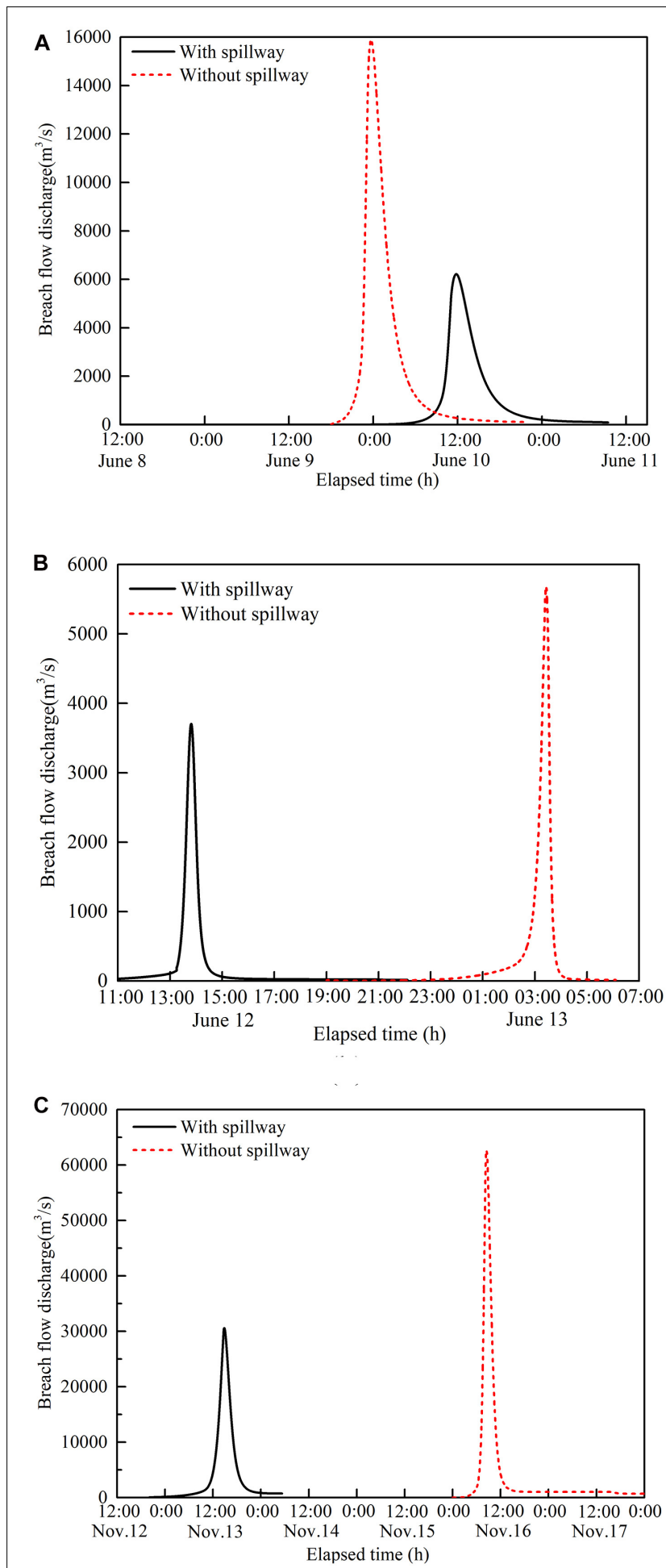

FIGURE 9 | Breach hydrographs with and without spillway excavation for the three landslide dams.

large boulders are washed away, the erosion speed accelerates, and the final peak breach flow charge increases, which is also very harmful.
TABLE 8 | Comparison of landslide dam breaching parameters with and without spillways.

\begin{tabular}{lcccc}
\hline Name & Spillway & $\boldsymbol{Q}_{\boldsymbol{p}}\left(\mathbf{m}^{\mathbf{3}} \mathbf{s}\right)$ & $\boldsymbol{D}_{\boldsymbol{f}}(\mathbf{m})$ & $\boldsymbol{T}_{\boldsymbol{p}} \mathbf{( h )}$ \\
\hline Tangjiashan & With & 6,500 & 35 & 49.92 \\
& Without & 15,874 & 42.4 & 37.65 \\
& & $144.22 \%$ & $21.14 \%$ & $-24.58 \%$ \\
Xiaogangjian & With & 3,950 & 40 & 3.0 \\
& Without & 5,647 & 38.6 & 17.6 \\
"11 03" Baige & & $42.96 \%$ & $3.50 \%$ & $486.67 \%$ \\
& With & 31,000 & 57.1 & 37.25 \\
& Without & 62,626 & 68.7 & 121.6 \\
& & $102.02 \%$ & $20.32 \%$ & $226.44 \%$ \\
\hline
\end{tabular}

For the "11.03" Baige landslide dam, the dam body is primarily composed of fine material. The peak discharge formed under the huge storage capacity is very large, with strong risks and hazards. Damage from the lake breach flood was significantly reduced by the organized emergency response. In the case without spillway excavation, the risk is amplified, the peak breach flow charge significantly increased, and the early erosion efficiency significantly decreased (Figure 9C).

In summary, spillway excavation exerts an important influence on the landslide dam breach process. For landslide dams of different types, the proposed numerical method can be used to simulate the breach process, analyze the influence of spillway excavation, and make rapid decisions during an actual emergency response.

\section{CONCLUSION}

This paper analyzed the breach process of landslide dams considering grain size distribution to provide rapid predictions for emergency response. The primary conclusions are as follows:

(1) Combined with the formation mechanism and the grain size distribution of landslide dams, a simplified and quick landslide dam classification scheme was developed.

(2) A numerical method considering the breach mechanism and stratification of landslide dams was proposed by modifying the model of Zhong et al. (2020a). Model input parameters can be obtained from geological surveys or empirical formulas, which allow for rapid prediction of the landslide dam breach process.

(3) Case studies of three representative landslide dams were presented to demonstrate the validity of the proposed numerical method. The comparison of the calculated and measured breach flow discharge, water level variation in the dammed lake, and breach size evolution indicated that the modified model can provide general predictions regarding the breach process. The grain size distribution of landslide dams has significant influence on the breach process.

(4) The influence of a spillway on the landslide dam breach was analyzed, and results indicated that spillway excavation can effectively reduce the peak breach flow discharge. 


\section{DATA AVAILABILITY STATEMENT}

The original contributions presented in the study are included in the article/supplementary material, further inquiries can be directed to the corresponding author/s.

\section{AUTHOR CONTRIBUTIONS}

SM: writing-original draft, calculation, and analysis. SC: supervision and funding acquisition. QZ: supervision, methodology, and funding acquisition. YS: methodology and

\section{REFERENCES}

ASCE/EWRI Task Committee on Dam/Levee Breach. (2011). Earthen embankment breaching. J. Hydraulic Eng. 137, 1549-1564. doi: 10.1061/(asce) hy.1943-7900.0000498

Cai, Y. J., Cheng, H. Y., Wu, S. F., Yang, Q. G., Wang, L., Luan, Y. S., et al. (2020). Breaches of the baige barrier lake: emergency response and dam breach flood. Sci. China Technol. Sci. 63, 1164-1176. doi: 10.1007/s11431-019$1475-y$

Chang, D. S., and Zhang, L. M. (2010). Simulation of the erosion process of landslide dams due to overtopping considering variations in soil erodibility along depth. Nat. Hazards Earth Syst. Sci. 10, 933-946. doi: 10.5194/nhess-10933-2010

Chang, D. S., Zhang, L. M., Xu, Y., and Huang, P. Q. (2011). Field testing of erodibility of two landslide dams trigged by the 12 may wenchuan earthquake. Landslides 8, 321-332. doi: 10.1007/s10346-011-0256-x

Chen, S. J., Chen, Z. Y., Tao, R., Yu, S., Xu, W. J., Zhou, X. B., et al. (2018). Emergency response and back analysis of the failures of earthquake triggered cascade landslide dams on the mianyuan river, china. Nat. Hazards Rev.19:05018005. doi: 10.1061/(asce)nh.1527-6996.0000285

Chen, Z. Y., Ma, L. Q., Yu, S., Chen, S. J., Zhou, X. B., Sun, P., et al. (2015). Back analysis of the draining process of the tangjiashan barrier lake. J. Hydraulic Eng. 141:05014011. doi: 10.1061/(asce)hy.1943-7900.0000965

Chen, Z. Y., Zhang, Q., Chen, S. J., Wang, L., and Zhou, X. B. (2020). Evaluation of barrier lake breach floods: Insights from recent case studies in china. Wiley Interdipl. Rev. Water 7, 1-16.

Costa, J. E., and Schuster, R. L. (1988). The formation and failure of natural dam. Geol. Soc. Am. Bull. 100, 1054-1068.

Cruden, D. M., and Varnes, D. J. (1996). "Landslide types and processes," in Landslides, investigation and mitigation: special report, Vol. 247, eds A. K. Turner and R. L. Schuster (New York City: transportation research board, national research council), 36-75.

Davies, T., and McSaveney, M. (2002). Dynamic simulation of the motion of fragmenting rock avalanches. Can. Geotech. J. 39, 789-798. doi: 10.1139/ t02-035

Dunning, S. A., and Armitage, P. J. (2011). "The grain-size distribution of rock-avalanche deposits: implications for natural dam stability," in Natural and Artificial Rockslide Dams, eds S. G. Evans, R. Hermanns, G. ScarasciaMugnozza, and A. L. Strom (Berlin, Germany: Springer), 479-498. doi: 10.1007/ 978-3-642-04764-0_19

Erismann, T. H., and Abele, G. (2013). Dynamics of Rockslides and Rockfalls. Berlin, Germany: Springer Science \& Business Media.

Evans, S. G., Delaney, K. B., Hermanns, R. L., Strom, A. L., and ScarasciaMugnozza, G. (2011). "The formation and behavior of natural and artificial rockslide dams: Implication for engineering performance and hazard management," in Natural and Artificial Rockslide Dams, eds S. G. Evans, R. L. Hermanns, A. Storm, and G. Scarascia-Mugnozza (Berlin, Germany: Springer), 1-75. doi: 10.1007/978-3-642-04764-0_1

Fan, X. M., Dufresne, A., Subramanian, S. S., Strom, A., Hermanns, R., Stefanelli, C. T., et al. (2020). The formation and impact on landslide dams - state of the art. Earth Sci. Rev. 203:103116. doi: 10.1016/j.earscirev.2020.103116 advise. All authors contributed to the article and approved the submitted version.

\section{FUNDING}

This work was financially supported by the National Key Research and Development Program of China (Grant No. 2018YFC1508604), National Natural Science Foundation of China (Grant Nos. U2040221, 51779153, and 51539006), and Fundamental Research Funds for Central Public Research Institutes (Grant Nos. Y319003 and Y320005).

Fan, X. M., Xu, Q., van Westen, C. J., Huang, R. Q., and Tang, R. (2017). Characteristics and classification of landslide dams associated with the 2008 wenchuan earthquake. Geoenviron. Disas. 4:12.

Fread, D. L. (1984). DAMBREAK: The NWS Dam Break Flood Forecasting Model. Silver Spring, USA: National Oceanic and Atmospheric Administration.

Gruber, N., Gloor, M., Mikaloff Fletcher, S. E., Doney, S. C., Dutkiewicz, S., Follows, M. J., et al. (2009). Oceanic sources, sinks, and transport of atmospheric $\mathrm{CO}_{2}$. Global Biogeochem. Cycles 23, 1-21.

Liu, N., Yang, Q. G., and Chen, Z. Y. (2016). Hazard mitigation for barrier lakes. Wuhan, China: Changjiang River publication.

Niu, Z. P., Xu, W. L., Li, N. W., Xue, Y., and Chen, H. Y. (2012). Experimental investigation of the failure of cascade landslide dams. J. Hydrodynamics 24, 430-441. doi: 10.1016/s1001-6058(11)60264-3

Peng, M., and Zhang, L. M. (2012). Breaching parameters of landslide dams. Landslides 9, 13-31. doi: 10.1007/s10346-011-0271-y

Peng, M., Zhang, L. M., Chang, D. S., and Shi, Z. M. (2014). Engineering risk mitigation measures for the landslide dams induced by the 2008 wenchuan earthquake. Eng. Geol. 180, 68-84. doi: 10.1016/j.enggeo.2014. 03.016

Shen, D. Y., Shi, Z. M., Peng, M., Zhang, L. M., and Jiang, M. Z. (2020). Longevity analysis of landslide dams. Landslides 17, 1797-1821. doi: 10.1007/s10346-02001386-7

Shi, Z. M., Wang, Y. Q., Chen, J. F., Sheng, Z. G., and He, X. T. (2011). Effect of fill size on the stability of barrier dams. Appl. Mech. Mat. 9, 1373-1382. doi: 10.4028/www.scientific.net/amm.90-93.1373

Wang, L., Chen, Z. Y., Wang, N. X., Sun, P., Yu, S., Li, S. Y., et al. (2016). Modeling lateral enlargement in dam breaches using slope stability analysis based on circular slip mode. Eng. Geol. 209, 70-81. doi: 10.1016/j.enggeo.2016. 04.027

Wu, W. M. (2013). Simplified physically based model of earthen embankment breaching. J. Hydraulic Eng. 139, 837-851. doi: 10.1061/(asce)hy.1943-7900. 0000741

Zhang, J., Cao, S. Y., Yang, F. G., Luo, L. H., and Huang, E. (2010). Experimental study on outlet and scour of blocked dam. Adv. Eng. Sci. 42, 191-196.

Zhang, L. M., Xiao, T., He, J., and Chen, C. (2019). Erosion-based analysis of breaching of baige landslide dams on the jinsha river, china, in 2018. Landslides 16, 1965-1979. doi: 10.1007/s10346-019-01247-y

Zhao, T. L., Chen, S. S., Fu, C. J., and Zhong, Q. M. (2019). Centrifugal model tests and numerical simulations for barrier dam break due to overtopping. J. Mountain Sci. 16, 630-640. doi: 10.1007/s11629-018-5024-0

Zhong, Q. M., Chen, S. S., Mei, S. A., and Cao, W. (2018). Numerical simulation of landslide dam breaching due to overtopping. Landslides 15, 1183-1192. doi: 10.1007/s10346-017-0935-3

Zhong, Q. M., Chen, S. S., and Shan, Y. B. (2020a). Predicting the overtoppinginduced breach process of the landslide dam. Eng. Geol. 274:105709. doi: 10.1016/j.enggeo.2020.105709

Zhong, Q. M., Chen, S. S., Wang, L., and Shan, Y. B. (2020b). Back analysis of breaching process of baige landslide dam. Landslides 17, 1-12.

Zhong, Q. M., and Wu, W. M. (2016). Discussion of "back analysis of the draining process of the tangjiashan barrier lake" by Zuyu Chen, 
Liqiu Ma, Shu Yu, Shujing Chen, Xingbo Zhou, Ping Sun, and Xu Li. J. Hydraulic Eng. 142:07016001. doi: 10.1061/(asce)hy.1943-7900.000 1161

Zhong, Q. M., Wu, W. M., Chen, S. S., and Wang, M. (2016). Comparison of simplified physically based dam breach models. Nat. Hazards 84, 1385-1418. doi: 10.1007/s11069-016-2492-9

Zhou, G. G. D., Zhou, M. J., Shrestha, M. S., Song, D. R., Choi, C. E., Cui, K. F. E., et al. (2019). Experimental investigation on the longitudinal evolution of landslide dam breaching and outburst floods. Geomorphology 334, 29-43. doi: 10.1016/j.geomorph.2019.02.035
Conflict of Interest: The authors declare that the research was conducted in the absence of any commercial or financial relationships that could be construed as a potential conflict of interest.

Copyright (c) $2021 \mathrm{Mei}$, Chen, Zhong and Shan. This is an open-access article distributed under the terms of the Creative Commons Attribution License (CC BY). The use, distribution or reproduction in other forums is permitted, provided the original author(s) and the copyright owner(s) are credited and that the original publication in this journal is cited, in accordance with accepted academic practice. No use, distribution or reproduction is permitted which does not comply with these terms. 